\title{
PENGARUH GAYA BELAJAR DAN PERSEPSI SISWA MENGENAI VARIASI MENGAJAR GURU TERHADAP HASIL BELAJAR MATEMATIKA SISWA KELAS VIII SMP NEGERI 5 KENDARI
}

\author{
Waode Siti Khadijah Tulqubra ${ }^{1)}$, Muhammad Sudia ${ }^{2)}$, La Ode Ahmad Jazuli ${ }^{3)}$ \\ ${ }^{1)}$ Alumni Jurusan Pendidikan Matematika, ${ }^{2,3)}$ Dosen Jurusan Pendidikan Matematika \\ FKIP Universitas Halu Oleo. Email: sitikhadijahtulqubra@gmail.com; \\ muhammad_matematika@yahoo.co.id; Ahmadjazuli_laode@yahoo.com;
}

\begin{abstract}
Abstrak
Penelitian ex post facto ini bertujuan untuk mengetahui pengaruh gaya belajar dan persepsi siswa mengenai variasi mengajar guru terhadap hasil belajar matematika. Populasi penelitian ini adalah seluruh siswa kelas VIII SMP Negeri 5 Kendari sebanyak 429 siswa dengan teknik purposive sampling diperoleh sampel penelitian sebanyak 172 siswa. Teknik pengumpulan data variabel diperoleh melalui angket dan dokumentasi. Teknik analisis data menggunakan analisis statistik deskriptif dan analisis inferensial.Hasil pengujian hipotesis diperoleh bahwa: 1) ada perbedaan ratarata antar gaya belajar siswa dimana gaya belajar visual memiliki rata-rata yang lebih tinggi daripada kinestetik dan auditorial; 2) ada pengaruh signifikan gaya belajar terhadap hasil belajar matematika dengan pengaruh sebesar $18,7 \%$; 3) ada pengaruh signifikan persepsi siswa mengenai variasi mengajar guru terhadap hasil belajar matematika dengan pengaruh sebesar 2,9\%; 4) ada pengaruh signifikan gaya belajar dan persepsi siswa mengenai variasi mengajar guru secara bersama-sama terhadap hasil belajar matematika dengan pengaruh sebesar 19,7\% dansisanya $80,3 \%$ dipengaruhi oleh variabel lain.
\end{abstract}

Kata Kunci: gaya belajar, persepsi siswa, hasil belajar matematika

\section{THE INFLUENCE OF LEARNING STYLES AND STUDENT'S PERCEPTIONS ABOUT THE VARIATIONS OF TEACHERS TEACHING ON STUDENT'S MATHEMATICS LEARNING OUTCOMES CLASS VIII SMP NEGERI 5 KENDARI}

\begin{abstract}
This ex post facto research aims to find out the influence of learning styles and students' perceptions about teacher teaching variation on mathematics learning outcomes. The population of this study is all students of class VIII SMP Negeri 5 Kendari as many as 429 students with purposive sampling technique obtained by the sample of 172 students. Data collection techniques of variables obtained through questionnaires and documentation. Data analysis techniques used descriptive statistical analysis and inferential analysis. Hypothesis testing results obtained that: 1) there is an average difference between student learning styles in which the visual learning style has a higher average than kinesthetic and auditorial; 2) there is a significant influence of learning style on mathematics learning result with influence of $18,7 \% ; 3$ ) there is a significant influence of student perception about teacher teaching variation on mathematics learning result with influence of $2.9 \%$; 4 ) there is a significant influence of learning styles and students' perceptions of the variation of teaching teachers together on the results of learning mathematics with the influence of $19.7 \%$ and the remaining $80,3 \%$ influenced by other variables.
\end{abstract}

Keywords: learning styles, students perceptions, mathematics learning outcomes 


\section{Pendahuluan}

Pendidikan merupakan pilar utama dalam membangun sumber daya manusia dan menjadi kunci pembangunan masa mendatang bagi bangsa Indonesia. Sebab dengan pendidikan diharapkan setiap individu dapat meningkatkan kualitas keberadaannya dan mampu berpartisipasi dalam gerak pembangunan. Definisi modern pendidikan dinyatakan sebagai proses penyadaran yang terjadi karena interaksi pelbagai faktor yang menyangkut manusia dan potensinya serta alam lingkungan dan kemungkinan-kemungkinan di dalamnya (Mulyadi, 2016: 2).Pembangunan mutu pendidikan diarahkan sejalan dengan perkembangan ilmu pengetahuan dan teknologi di samping pembangunan bidang-bidang lain yang dilaksanakan oleh pemerintah.

Kemajuan ilmu pengetahuan dan teknologi tidak terlepas dari pengaruh matematika yang merupakan dasar bagi disiplin ilmu yang lain. Hal ini terbukti dengan diwajibkannya pelajaran matematika yang mulai diajarkan dari jenjang sekolah dasar hingga pendidikan tinggi. Ini dikarenakan mata pelajaran matematika berfungsi untuk mengembangkan kemampuan berkomunikasi dengan menggunakan bilangan dan simbolsimbol serta ketajaman penalaran yang dapat membantu memperjelas dan menyelesaikan permasalahan dalam kehidupan sehari-hari (Winataputra, 2000: 1.25). Artinya, belajar matematika berkaitan erat dengan aktivitas proses belajar dan berpikir yang seringkali digunakan dalam kehidupan sehari-hari. Menyadari akan pentingnya peranan matematika, maka mata pelajaran matematika perlu mendapat perhatian khusus. Begitu pula dengan pencapaian hasil belajar matematika siswa setelah mengikuti proses belajar di sekolah.Pada dasarnya belajar merupakan tahapan perubahan perilaku siswa yang relatif positif dan mantap sebagai hasil interaksi dengan lingkungan yang melibatkan proses kognitif, dengan kata lain belajar merupakan kegiatan berproses yang terdiri dari beberapa tahap (Jihad dan Haris, 2012: 1).Menurut Sudjana (Jihad dan Haris, 2012: 2), belajar adalah suatu proses yang ditandai dengan adanya perubahan pada diri seseorang, perubahan sebagai hasil proses belajar dapat ditunjukkan dalam berbagai bentuk seperti perubahan pengetahuan, pemahaman, sikap dan tingkah laku, keterampilan, kecakapan, kebiasaan serta perubahan aspek-aspek yang ada pada individu yang belajar.

Hasil belajar siswa pada hakikatnya adalah perubahan tingkah laku yang mencakup bidang kognitif, afektif, psikomotoris.Hasil belajar adalah kemampuan yang diperoleh anak setelah melalui kegiatan belajar. Belajar itu sendiri merupakan suatu proses dari seseorang yang berusaha untuk memperoleh suatu bentuk perubahan perilaku yang relatif menetap (Jihad dan Haris, 2012: 14). Menurut Hudojo, matematika adalah suatu bidang ilmu yang melatih penalaran agar dapat berpikir logis dan sistematis dalam menyelesaikan masalah dan membuat keputusan. Mempelajari matematika memerlukan cara tersendiri karena matematika pun bersifat khas yaitu abstrak, konsisten, hierarki, dan berpikir deduktif (Septiana, 2016: 166). Sedangkan dalam Kamus Besar Bahasa Indonesia (Tim Penyusun KBBI, 2007:723) matematika diartikan sebagai: "ilmu tentang bilangan, hubungan antara bilangan, dan prosedur bilangan operasional yang digunakan dalam penyelesaian masalah mengenai bilangan". Dari beberapa pendapat yang dikemukakan di atas, maka dapat disimpulkan bahwa hasil belajar matematika adalah wujud pencapaian peserta didik sebagai hasil akhir dari proses belajar dengan adanya perubahan tingkah laku yang dimiliki oleh siswa berupa kemampuan pemahaman tentang bentuk, susunan, besaran dan konsep-konsep yang saling berhubungan satu sama lain yang menggunakan istilah serta didefinisikan dengan cermat setelah siswa tersebut menerima pengalamannya dalam proses belajar.

Menurut Purwanto berhasil atau tidaknya perubahan tingkah laku tersebut dipengaruhi oleh berbagai macam faktor yang dibedakan menjadi dua golongan yaitu: 1) faktor yang ada pada diri organisme tersebut yang disebut faktor individual. Faktor individual meliputi hal-hal berikut: a) faktor kematangan atau pertumbuhan; b) faktor kecerdasan atau intelegensi; c) faktor latihan dan ulangan; d) faktor motivasi; dan e) faktor pribadi dan 2) faktor yang ada diluar individu yang disebut faktor sosial. Termasuk ke dalam faktor diluar individual atau faktor sosial antara lain: a) faktor keluarga atau keadaan rumah tangga; b) faktor guru dan cara mengajarnya; c) faktor alat-alat yang digunakan dalam belajar-mengajar; d) 
faktor lingkungan dan kesempatan yang tersedia; dan e) faktor motivasi sosial (Thobroni, 2016: 12). Berdasar dari faktor-faktor yang mempengaruhi hasil belajar tersebut, diduga salah satu faktor internal yang mempengaruhi hasil belajar matematika siswa kelas VIII SMP Negeri 5 Kendari tahun pelajaran 2016/2017 adalah gaya belajar siswa.

Gaya belajar seseorang adalah kombinasi dari bagaimana ia menyerap, dan kemudian mengatur serta mengolah informasi. Karena itu, untuk mengatasi gaya belajar telah disepakati secara umum adanya dua kategori utama bagaimana seseorang belajar yaitu pertama, bagaimana seseorang menyerap informasi dengan mudah (modalitas) dan kedua, cara seseorang mengolah dan mengatur informasi tersebut (dominasi otak). Jadi, gaya belajar adalah kombinasi dari bagaimana ia menyerap, dan kemudian mengatur serta mengolah informasi (Deporter dan Hernacki, 2015: 112).Gaya belajar mengacu pada cara belajar yang lebih disukai siswa. Kemampuan seorang siswa dalam menyerap dan memahami pelajaran berbeda-beda tingkatannya ada yang cepat, sedang, bahkan lambat tergantung dari gaya belajar mereka masing-masing. Pada umumnya siswa belajar dengan menggunakan cara termudah dalam menerima dan menyerap informasi atau biasa disebut melalui modalitas belajar. Banyak model-model gaya belajar yang dikemukakan, namun yang menjadi perhatian utama adalah gaya belajar berdasarkan modalitas individu.

Gaya belajar berdasarkan modalitas seseorang ini terdiri dari modalitas visual, auditorial, dan kinestetik. 1) Orang visual belajar melalui apa yang mereka lihat, ciri-cirinya antara lain: mengingat apa yang dilihat, daripada apa yang didengar; mengingat dengan asosiasi visual; dan mencoret-coret tanpa arti selama berbicara di telepon dan dalam rapat. 2) pelajar auditorial belajar melalui apa yang mereka dengar, ciri-cirinya antara lain: berbicara kepada diri sendiri saat bekerja; mudah terganggu oleh keributan; menggerakkan bibir mereka dan mengucapkan tulisan di buku ketika membaca. Terakhir 3) pelajar kinestetik belajar lewat gerak dan sentuhan, ciri-cirinya antara lain:menanggapi perhatian fisik; menyentuh orang untuk mendapatkan perhatian mereka; dan menghafal dengan cara berjalan dan melihat. Karena itu, siswa seringkali menggunakan cara yang berbeda untuk bisa menyerap dan memahami informasi yang sama. Terdapat beberapa faktor yang mempengaruhi gaya belajar. Rita Dunn, seorang pelopor di bidang gaya belajar telah menemukan banyak variabel yang mempengaruhi cara belajar seseorang. Faktor-faktor tersebut mencakup: faktor fisik, faktor emosional, faktor sosiologis, dan faktor lingkungan.

Sebagai guru, sudah seharusnya melayani siswa yang mempunyai gaya belajar yang berbeda-beda. Untuk itu, terdapat strategi untuk mempermudah gaya belajar siswa. 1) Strategi yang dilakukan untuk mempermudah proses belajar siswa yang bertipe visual: (a) gunakan materi visual seperti gambar, diagram dan peta, (b) gunakan warna yang terang untuk menandai hal-hal yang penting, (c) ajak siswa untuk membaca buku-buku berilustrasi, (d) gunakan multimedia (contohnya: komputer dan video), dan (e) ajak siswa untuk mencoba mengilustrasikan ide-idenya dalam gambar. 2) Strategi yang dilakukan untuk mempermudah proses belajar siswa yang bertipe auditorial: (a) ajak anak untuk ikut berpartisipasi dalam diskusi baik di dalam kelas maupun di dalam keluarga, (b) dorong anak untuk membaca materi pelajaran dengan keras, (c) diskusikan ide dengan anak secara verbal, (d) biarkan anak merekam materi pelajarannya ke dalam kaset dan dorong dia untuk mendengarkannya sebelum tidur. 3) Strategi yang dilakukan untuk mempermudah proses belajar siswa yang bertipe kinestetik: (a) jangan paksakan anak untuk belajar sampai berjam-jam, (b) ajak anak untuk belajar sambil mengeksplorasi lingkungannya (gunakan obyek sesungguhnya untuk belajar konsep baru), (c) izinkan anak untuk mengunyah permen karet pada saat belajar, (d) gunakan warna yang terang untuk menandai hal-hal yang penting dalam bacaan. (Fatma, 2010: 48-49)

Berdasar pada yang dikemukakan Purwanto, salah satu faktor di luar individu yang mempengaruhi keberhasilan belajar adalah faktor guru dan cara mengajarnya. Informasi lain yang diperoleh dari hasil wawancara ke beberapa siswa pada saat observasi awal terdapat beberapa fakta yakni pada saat pembelajaran ada siswa yang harus memusatkan perhatiannya dalam arti harus fokus pada apa yang ditulis oleh guru di papan tulis, selain itu ada siswa yang lebih senang belajar berkelompok dengan diskusi karena mereka dapat mengeluarkan ide dan pendapat mereka. Bahkan, ada juga siswa yang tidak bisa 
mengulangi materi yang sama secara berulang kali karena hal tersebut dapat membuat daya ingatnya akan materi tertentu berkurang. Dari itu, dapat diketahui bahwa persepsi siswa juga sangat berpengaruh terhadap hasil belajar. Menurut Echhols dan Shadily (Sartika, 2013: 12) kata persepsi berasal dari bahasa Inggris "perception" yang berarti tanggapan atau daya memahami maksudnya adalah suatu respon yang timbul setelah terjadi penginderaan. Sedang Slameto (2015: 102) menjelaskan bahwa persepsi adalah proses yang menyangkut masuknya pesan atau informasi ke dalam otak manusia. Melalui persepsi, manusia terus menerus mengadakan hubungan dengan lingkungannya melalui inderanya, yaitu indera penglihatan, peraba, perasa, penciuman dan pendengaran. Jadi, faktor lain dalam penelitian ini adalah persepsi siswa mengenai variasi mengajar guru.

Variasi mengajar merupakan suatu hal yang harus dilakukan oleh seorang guru pada saat mengajar di kelas. Variasi sangat diperlukan dalam kegiatan pembelajaran sebab siswa akan menjadi sangat bosan jika guru selalu mengajar dengan cara yang sama. Oleh karena itu, sudah seharusnya guru melakukan variasi pada saat proses belajar-mengajar baik itu mengadakan variasi dalam gaya mengajar, variasi dalam penggunaan media dan bahan pembelajaran, maupun variasi dalam pola interaksi dan kegiatan. Apabila ketiga komponen variasi ini dikombinasikan, maka akan meningkatkan perhatian siswa dan membangkitkan semangat belajar siswa.Variasi dapat berwujud perubahanperubahan atau pebedaan-perbedaan yang sengaja diciptakan/dibuat untuk memberikan kesan yang unik. Variasi di dalam kegiatan pembelajaran bertujuan antara lain untuk: 1) menghilangkan kebosanan siswa dalam belajar; 2) meningkatkan motivasi siswa dalam mempelajari sesuatu; 3) mengembangkan keinginan siswa untuk mengetahui dan menyelidiki hal-hal baru; 4) melayani gaya belajar siswa yang beraneka ragam; serta 5) meningkatkan kadar keaktifan/keterlibatan siswa dalam kegiatan pembelajaran. (Winataputra, 2000: 7.45 - 7.46). Pada dasarnya, variasi dalam kegiatan pembelajaran dapat dikelompokkan menjadi 3 bagian, yakni: Variasi dalam gaya mengajar, Variasi dalam penggunaan media dan bahan pembelajaran, Variasi dalam pola interaksi dan kegiatan.
Menurut Usman (Aqib, 2013: 67) mengajar adalah suatu proses yang mengandung serangkaian perbuatan guru dan siswa atas dasar hubungan timbal balik yang berlangsung dalam situasi edukatif untuk mencapai tujuan tertentu. Berdasarkan berbagai pendapat yang telah dikemukakan di atas, maka dapat disimpulkan bahwa variasi mengajar guru adalah cara guru dalam mengadakan perubahan-perubahan atau pebedaan-perbedaan pada saat memberikan materi, membimbing siswa pada saat kegiatan pembelajaran dengan melakukan hubungan timbal balik antara guru dan siswa baik perubahan dalam gaya mengajar, penggunaan media dan bahan pembelajaran maupun pola interaksi dan kegiatan dalam kelas sehingga dapat menumbuhkembangkan motivasi, rasa semangat siswa serta aktivitas siswa dalam belajar.

Gaya belajar dan persepsi siswa mengenai variasi mengajar guru erat kaitannya dan saling mempengaruhi satu sama lain. Apabila guru memahami gaya belajar siswa, maka guru dapat memiliki dasar dalam menentukan gaya mengajar, bahan dan media pembelajaran apa yang relevan dengan gaya belajar siswa dan menciptakan suasana belajar yang cocok dengan gaya belajar siswa disetiap kegiatan pembelajaran sehingga suasana kelas bisa menjadi lebih efektif dan menyenangkan. Hal ini pun, akan membuat siswa semangat untuk mengikuti pelajaran dan tercipta persepsi baik dalam benak siswa mengenai variasi mengajar yang dilakukan guru pada saat pembelajaran. Begitupun sebaliknya, jika guru tidak memahami gaya belajar siswa maka guru akan kesulitan menentukan cara mengajar yang sesuai dengan gaya belajar siswa sehingga proses pembelajaran berlangsung secara monoton dan membuat siswa menjadi jenuh dalam mengikuti kegiatan pembelajaran.

\section{Metode}

Penelitian ex post facto adalah penelitian secara empiris yang sistematik, dimana peneliti tidak mempunyai kontrol langsung terhadap variabel-variabel bebas (independent variables) karena manifestasi fenomena telah terjadi atau karena fenomena sukar dimanipulasikan (Nazir,2011:73). Penelitian ini dilakukan untuk mengungkap peristiwa yang sudah terjadi, dan kemudian meruntut kebelakang untuk mengetahui faktor- 
faktor yang dapat menimbulkan kejadian tersebut (Sujarweni, 2014: 8). Penelitian ini dilaksanakan di SMP Negeri 5 Kendari yang terletak di JalanKelapaNomor 1 AnduonohuKec. Poasia, Kendari dari tanggal 14 Februari-22 Maret 2017 semester genap tahun ajaran 2016/2017.

Populasi dalam penelitian ini adalah seluruh siswa kelas VIII SMP Negeri 5 Kendari tahun ajaran 2016/2017 yang tersebar merata dalam 11 kelas pararel dengan jumlah keseluruhan siswa sebanyak 430 siswa yang diajar oleh 3 (tiga) orang guru matematika. Sampel yang digunakan dalam penelitian ini adalah kelas $\mathrm{VIII}_{\mathrm{G}}$, VIII $\mathrm{H}$, VIII, $\mathrm{VIII}_{\mathrm{J}}$ dan $\mathrm{VIII}_{\mathrm{K}}$ yang berjumlah 172 siswa. Teknik pengambilan sampel menggunakan teknik purposive sampling yang didasarkan pada pertimbanganpertimbangan jumlah yang sudah ditentukan. Dalam penelitian ini, terdapat dua variabel bebas dan satu variabel terikat. Variabel bebasnya adalah gaya belajar $\left(\mathrm{X}_{1}\right)$ dan persepsi siswa mengenai variasi mengajar guru $\left(\mathrm{X}_{2}\right)$, sedangakan variabel terikat pada penelitian ini adalah hasil belajar matematika $(\mathrm{Y})$.

Desain hubungan antara dua variabel bebas terhadap variabel terikat baik secara terpisah maupun secara bersama-sama ditunjukan pada gambar 1 berikut:

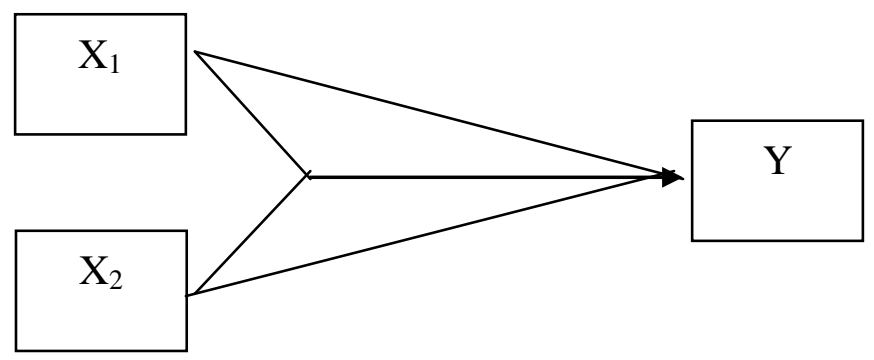

Gambar 1. Hubungan antara variabel bebas dan variabel terikat

Dalam penelitian ini digunakan analisis
statistik deskriptif dan analisis inferensial.Analisis deskriptif dimaksudkan untuk mendeskripsikan atau menggambarkan variabel-variabel penelitian yaitu gaya belajar, persepsi siswa mengenai variasi mengajar guru dan hasil belajar matematika dalam bentuk mean, median, modus, standar deviasi, nilai minimum, nilai maksimum dan persentase. Analisis inferensial yang digunakan untuk menguji hipotesis yaitu uji anava satu arah (one way anova), analisis regresi linear sederhana dan analisis regresi berganda dengan bantuan SPSS 15 for windowsevaluation version.

\section{Hasil}

Hasil analisis deskriptif data angket gaya belajar siswa distribusi skor yang diperoleh untuk: 1) gaya belajar visual nilai yang diperoleh mulai dari 31,33 (skor minimum) sampai dengan 55,08 (skor maksimum). Ratarata skor gaya belajar siswa adalah 43,17, median 43,16 dan modus 51,31 dengan standar deviasi sebesar 4,66. 2) gaya belajar auditorial nilai yang diperoleh mulai dari 32,01 (skor minimum) sampai dengan 55,47 (skor maksimum). Rata-rata skor gaya belajar siswa adalah 41,34, median 41,29 dan modus 43,67 dengan standar deviasi sebesar 3,84. 3) gaya belajar kinestetik nilai yang diperoleh mulai dari 30,91 (skor minimum) sampai dengan 52,66 (skor maksimum). Rata-rata skor gaya belajar siswa adalah 41,53, median 41,15 dan modus 44,03 dengan standar deviasi sebesar 4,6. Distribusi gaya belajar siswa kelas VIII SMP Negeri 5 Kendari selengkapnya dapat dilihat pada tabel 1 . 
Tabel 1

Distribusi Gaya Belajar Siswa Kelas VIII SMP Negeri 5 Kendari

\begin{tabular}{|c|l|c|c|c|}
\hline No & Gaya Belajar & Frekuensi & Persentase (\%) & Rata-Rata HBM \\
\hline 1 & Visual & 72 & 41,86 & 70,4 \\
\hline 2 & Auditorial & 46 & 26,74 & 63,8 \\
\hline 3 & Kinestetik & 54 & 31,4 & 69,13 \\
\hline \multicolumn{2}{|c|}{ Jumlah } & 172 & 100 & \\
\hline
\end{tabular}

Hasil analisis deskriptif data angket adalah 55,98, median 56,01 dan modus 58,93 persepsi siswa mengenai variasi mengajar guru dengan standar deviasi sebesar 5,03. Tingkat distribusi skor yang diperoleh mulai dari 43,99 persentase persepsi siswa mengenai variasi (skor minimum) sampai dengan 68,53 (skor mengajar guru selengkapnya dapat dilihat pada maksimum). Rata-rata skor gaya belajar siswa tabel 2.

Tabel 2

Persentase Persepsi Siswa mengenai Variasi Mengajar Guru

\begin{tabular}{|c|c|c|c|c|c|c|c|c|c|}
\hline \multirow[t]{2}{*}{ Dimensi } & \multirow[t]{2}{*}{ Indikator } & \multicolumn{3}{|c|}{$\begin{array}{c}\text { Persentase } \\
\text { Indikator }(\%)\end{array}$} & \multicolumn{3}{|c|}{ Kriteria } & \multirow{2}{*}{$\begin{array}{c}\text { Persentase } \\
\text { Indikator } \\
\text { (Total) }\end{array}$} & \multirow{2}{*}{$\begin{array}{r}\text { Persentase } \\
\text { Dimensi }\end{array}$} \\
\hline & & V & A & $\mathrm{K}$ & V & A & $\mathrm{K}$ & & \\
\hline \multirow{6}{*}{$\begin{array}{l}\text { 1. Variasi } \\
\text { dalam Gaya } \\
\text { Mengajar } \\
\text { Guru }\end{array}$} & $\begin{array}{l}\text { A.Memberi variasi dalam } \\
\text { nada suara, volume } \\
\text { suara, kecepatan bicara } \\
\text { dan intonasi }\end{array}$ & 66,81 & 64,56 & 65,82 & $\mathrm{CB}$ & $\mathrm{CB}$ & CB & $65,90 \%$ & \multirow{6}{*}{$74,00 \%$} \\
\hline & $\begin{array}{l}\text { B. Mengadakan perubahan } \\
\text { mimik dan gerak } \\
\text { tangan/badan untuk } \\
\text { memperjelas penyajian } \\
\text { materi }\end{array}$ & 62,48 & 69,55 & 64,86 & $\mathrm{CB}$ & $\mathrm{CB}$ & $\mathrm{CB}$ & $63,70 \%$ & \\
\hline & $\begin{array}{l}\text { C. Memberikan waktu } \\
\text { senyap/hening dalam } \\
\text { pembicaraannya dan } \\
\text { setelah memberikan } \\
\text { pertanyaan }\end{array}$ & 77,59 & 74,59 & 69,50 & B & B & $\mathrm{CB}$ & $74,25 \%$ & \\
\hline & $\begin{array}{l}\text { D. Melakukan kontak } \\
\text { pandang dengan siswa } \\
\text { saat mengajar }\end{array}$ & 82,24 & 78,52 & 79,94 & B & B & B & $80,51 \%$ & \\
\hline & $\begin{array}{l}\text { E. Melakukan perubahan } \\
\text { posisi pada saat } \\
\text { mengajar }\end{array}$ & 75,57 & 75,41 & 75,67 & B & B & B & $75,55 \%$ & \\
\hline & $\begin{array}{l}\text { F. Memusatkan perhatian } \\
\text { siswa dengan kata-kata }\end{array}$ & 82,59 & 79,59 & 79,21 & B & B & B & $80,73 \%$ & \\
\hline \multirow{2}{*}{$\begin{array}{l}\text { 2. Variasi } \\
\text { Penggunaan } \\
\text { Media dan } \\
\text { Bahan } \\
\text { Pembelajaran }\end{array}$} & $\begin{array}{l}\text { G. Menggunakan alat } \\
\text { bantu yang dapat dilihat }\end{array}$ & 62,45 & 60,08 & 62,19 & $\mathrm{CB}$ & $\mathrm{CB}$ & $\mathrm{CB}$ & $61,73 \%$ & \multirow[b]{2}{*}{$57,78 \%$} \\
\hline & $\begin{array}{l}\text { H. Menggunakan berbagai } \\
\text { suara langsung rekaman } \\
\text { dalam pengajarannya }\end{array}$ & 56,32 & 59,01 & 58,41 & KB & $\mathrm{CB}$ & CB & $57,69 \%$ & \\
\hline
\end{tabular}




\begin{tabular}{|c|c|c|c|c|c|c|c|c|c|}
\hline & $\begin{array}{l}\text { I. } \text { Memberikan } \\
\text { kesempatan pada siswa } \\
\text { memegang manipulasi } \\
\text { alat bantu pengajaran }\end{array}$ & 54,78 & 52,01 & 54,43 & $\mathrm{~KB}$ & $\mathrm{~KB}$ & $\mathrm{~KB}$ & $53,93 \%$ & \\
\hline \multirow{2}{*}{$\begin{array}{l}\text { 3. Variasi Pola } \\
\text { Interaksi dan } \\
\text { Kegiatan }\end{array}$} & $\begin{array}{l}\text { J. Menerapkan berbagai } \\
\text { pola interaksi dan } \\
\text { kegiatan siswa }\end{array}$ & 88,87 & 83,06 & 81,81 & SB & B & B & $85,09 \%$ & \multirow{2}{*}{$73,80 \%$} \\
\hline & $\begin{array}{l}\text { K. Menerapkan berbagai } \\
\text { metode pengajaran }\end{array}$ & 63,35 & 61,94 & 61,89 & $\mathrm{CB}$ & CB & CB & $62,51 \%$ & \\
\hline
\end{tabular}

Hasil analisis deskriptif data variabel hasil belajar matematika siswa distribusi nilai hasil belajar matematika yang diperoleh siswa kelas VIII SMP Negeri 5 Kendari tahun ajaran 2016/2017 dimulai dari 35 (nilai minimum) sampai dengan 97 (nilai maksimum). Rata-rata nilai hasil belajar matematika sebesar 68,24 median 69,5 modus 70 dengan standar deviasi 14,26. Distribusi nilai hasil belajar matematika siswa kelas VIII SMP Negeri 5 Kendari selengkapnya dapat dilihat pada tabel 3 .

Tabel 3

Distribusi Nilai Hasil Belajar Matematika Siswa

\begin{tabular}{|c|c|c|c|l|}
\hline No. & Interval & Frekuensi & Persentase & \multicolumn{1}{|c|}{ Kriteria } \\
\hline 1 & $\mathrm{X} \geq 89,63$ & 14 & $8,14 \%$ & Sangat Tinggi \\
\hline 2 & $75,37<\mathrm{X} \leq 89,63$ & 44 & $25,58 \%$ & Tinggi \\
\hline 3 & $61,11<\mathrm{X} \leq 75,37$ & 57 & $33,14 \%$ & Sedang \\
\hline 4 & $46,85<\mathrm{X} \leq 61,11$ & 44 & $25,58 \%$ & Rendah \\
\hline 5 & $\mathrm{X} \leq 46,85$ & 13 & $7,56 \%$ & Sangat Rendah \\
\hline
\end{tabular}

Data yang telah dikumpulkan selanjutnya diuji persyaratan analisis yang meliputi uji normalitas, multikolinearitas dan uji autokorelasi. Uji normalitas dilakukan untuk menguji kenormalan data dengan menggunakan uji Kolmogorov-Smirnov dengan bantuan SPSS 15.0 for windowsevaluation version dan hasil uji normalitas diperoleh nilai Kolmogorov Smirnov Z untuk variabel gaya belajar sebesar 0,574 dengan Asymp. sig. (2-tailed) $=0,897>$ signifikan $(\alpha)=0,05$ artinya data sampel variabel gaya belajar berasal dari populasi yang berdistribusi normal. Nilai KolmogorovSmirnov Z untuk variabel persepsi siswa mengenai variasi mengajar guru sebesar 0,667 dengan Asymp. sig. (2-tailed) $=0,765>$ signifikan $(\alpha)=0,05$ artinya data sampel variabel persepsi siswa mengenai variasi mengajar guru berasal dari populasi yang berdistribusi normal. Nilai KolmogorovSmirnov Z untuk variabel hasil belajar matematika sebesar 0,800 dengan Asymp. sig. $(2$-tailed $)=0,544>$ signifikan $(\alpha)=0,05$ artinya data sampel variabel hasil belajar matematika siswa berasal dari populasi yang berdistribusi normal. Uji multikolinearitas diperoleh dengan bantuan SPSS 15 for windowsevaluation version dan diperoleh nilai tolerance untuk variabel gaya belajar dan persepsi siswa mengenai variasi mengajar matematika sebesar 0,974 >0,10 dan nilai VIF untuk kedua variabel bebas tersebut sebesar 1,027 < 10,00 dimana nilai tolerance dan VIF tersebut mendekati 1 artinya dalam regresi antara variabel gaya belajar $\left(\mathrm{X}_{1}\right)$ dan variabel persepsi siswa mengenai variasi mengajar guru $\left(\mathrm{X}_{2}\right)$ tidak terjadi multikolinearitas antar variabel bebas. Uji autokorelasi diperoleh dengan bantuan SPSS 15 for windowsevaluation version dan diperoleh nilai durbin-watson $=1,303$ berada pada interval $(-2<\mathrm{DW} \leq 2)$. Hal ini menunjukkan persamaan regresi tidak mengalami masalah autokorelasi.

Pengujian hipotesis dalam penelitian ini menggunakan uji ANOVA dan uji regresi. Hasil uji anova di peroleh nilai $\mathrm{f}_{\text {hitung }}=3,240$ dengan $\left.\mathrm{df}_{1} / \mathrm{df}_{2}\right)=2 / 169=3,05$ pada kolom signifikan diperoleh nilai sig. sebesar 0,042 . Karena sig. yang diperoleh $<0,05$ maka diambil keputusan $\mathrm{H}_{0}$ ditolak. Artinya, hasil belajar matematika antar gaya belajar siswa berbeda secara signifikan. Hasil uji lanjut diperoleh perbedaan 
rata-rata tiap pasangan gaya belajar selengkapnya dapat dilihat pada tabel 4.

Tabel 4

Perbedaan rata-rata tiap pasangan gaya belajar

\begin{tabular}{|c|c|c|c|c|c|c|c|}
\hline & \multirow[b]{2}{*}{ (I) Gaya Belajar } & \multirow[b]{2}{*}{ (J) Gaya Belajar } & \multirow{2}{*}{$\begin{array}{c}\text { Mean } \\
\text { Difference } \\
(\mathrm{I}-\mathrm{J})\end{array}$} & \multirow[b]{2}{*}{ Std. Error } & \multirow[b]{2}{*}{ Sig. } & \multicolumn{2}{|c|}{$95 \%$ Confidence Interval } \\
\hline & & & & & & Lower Bound & Upper Bound \\
\hline \multirow[t]{6}{*}{ Scheffe } & \multirow[t]{2}{*}{ Visual } & Auditorial & $6,59843^{*}$ & 2,65746 &, 048 & ,0356 & 13,1613 \\
\hline & & Kinestetik & 1,27315 & 2,53450 & ,882 & $-4,9861$ & 7,5324 \\
\hline & \multirow[t]{2}{*}{ Auditorial } & Visual & $-6,59843^{*}$ & 2,65746 & ,048 & $-13,1613$ &,- 0356 \\
\hline & & Kinestetik & $-5,32528$ & 2,82484 &, 172 & $-12,3015$ & 1,6510 \\
\hline & \multirow[t]{2}{*}{ Kinestetik } & Visual & $-1,27315$ & 2,53450 & ,882 & $-7,5324$ & 4,9861 \\
\hline & & Auditorial & 5,32528 & 2,82484 & 172 & $-1,6510$ & 12,3015 \\
\hline \multirow[t]{6}{*}{ Bonferroni } & \multirow[t]{2}{*}{ Visual } & Auditorial & $6,59843^{*}$ & 2,65746 & ,042 &, 1726 & 13,0243 \\
\hline & & Kinestetik & 1,27315 & 2,53450 & 1,000 & $-4,8554$ & 7,4017 \\
\hline & \multirow[t]{2}{*}{ Auditorial } & Visual & $-6,59843^{*}$ & 2,65746 & ,042 & $-13,0243$ &,- 1726 \\
\hline & & Kinestetik & $-5,32528$ & 2,82484 & ,183 & $-12,1559$ & 1,5053 \\
\hline & \multirow[t]{2}{*}{ Kinestetik } & Visual & $-1,27315$ & 2,53450 & 1,000 & $-7,4017$ & 4,8554 \\
\hline & & Auditorial & 5,32528 & 2,82484 & ,183 & $-1,5053$ & 12,1559 \\
\hline
\end{tabular}

*. The mean difference is signific ant at the .05 level.

Uji regresi sederhana antara variabel gaya belajar $\left(\mathrm{X}_{1}\right)$ terhadap hasil belajar matematika (Y) memiliki sig $=0,000$ ebih kecil dari $\alpha=0,05$ yang dipilih atau dengan memperhatikan $\mathrm{t}_{\text {hitung }}=$ 6,249 , selanjutnya dibandingkan dengan $t_{\text {tabel }}$ dengan $\mathrm{dn}=\mathrm{n}-1=172-1=171$. Bila taraf kesalahan $5 \%$ untuk uji dua pihak, maka $t_{\text {tabel }}=$ 1,974 . Ternyata $\mathrm{t}_{\text {hitung }}=6,249>\mathrm{t}_{\text {tabel }}=1,974$. Hal ini menunjukkan diterimanya hipotesis $\mathrm{H}_{1}$ dan tolak $\mathrm{H}_{0}$. Artinya ada pengaruh yang signifikan gaya belajar terhadap hasil belajar matematika siswa kelas VIII SMP Negeri 5 Kendari. Persamaan regresinya adalah $\hat{Y}=-17,992+0,684 X_{1} \quad$ artinya $\quad$ setiap kenaikan 1 satuan gaya belajar maka hasil belajar matematika akan meningkat sebesar 0,684 satuan. Berdasarkan tabel 5, tampak bahwa hubungan gaya belajar dengan hasil belajar matematika siswa ditunjukkan oleh koefisien korelasi $(\mathrm{R})$ sebesar 0,432. Besarnya pengaruh gaya belajar terhadap hasil belajar matematika dapat dilihat pada koefisien determinasi ( $\mathrm{R}$ Square) yaitu 0,187 artinya persentase sumbangan pengaruh gaya belajar hanya sebesar $18,7 \%$. Sedangkan sisanya sebesar $81,3 \%$ dipengaruhi oleh faktor lain yang tidak diteliti dalam penelitian ini.

\section{Tabel 5}

Hasil Koefisien Korelasi Gaya Belajar terhadap Hasil Belajar Matematika Siswa

Model Summary

\begin{tabular}{|l|r|r|r|r|}
\hline Model & $\mathrm{R}$ & $\mathrm{R}$ Square & $\begin{array}{c}\text { Adjusted } \\
\text { R Square }\end{array}$ & $\begin{array}{c}\text { Std. Error of } \\
\text { the Estimate }\end{array}$ \\
\hline 1 &, $432^{\mathrm{a}}$ &, 187 &, 182 & 12,89914 \\
\hline
\end{tabular}

a. Predictors: (Constant), Gaya_Belajar

Uji regresi sederhana antara variabel persepsi siswa mengenai variasi mengajar guru $\left(\mathrm{X}_{2}\right)$ terhadap hasil belajar matematika (Y) memiliki sig $=0,026$ ebih kecil dari $\alpha=0,05$ yang dipilih atau dengan memperhatikan $t_{\text {hitung }}=2,247$, selanjutnya dibandingkan dengan $\mathrm{t}_{\text {tabel }}$ dengan $\mathrm{dn}$ $=\mathrm{n}-1=172-1=171$. Bila taraf kesalahan $5 \%$ untuk uji dua pihak, maka $t_{\text {tabel }}=1,974$. Ternyata $\mathrm{t}_{\text {hitung }}=2,247>\mathrm{t}_{\text {tabel }}=1,974$. Hal ini menunjukkan diterimanya hipotesis $\mathrm{H}_{1}$ dan tolak
$\mathrm{H}_{0}$. Artinya ada pengaruh yang signifikan persepsi siswa mengenai variasi mengajar guru terhadap hasil belajar matematika siswa kelas VIII SMP Negeri 5 Kendari. Persamaan regresinya adalah $\hat{Y}=41,274+0,482 X_{2}$ artinya jika persepsi siswa mengenai variasi mengajar guru adalah nol maka hasil belajar matematika yang diprediksi adalah 41,274 dan setiap kenaikan 1 satuan persepsi siswa 
mengenai variasi mengajar guru maka hasil belajar matematika akan meningkat sebesar 0,482 satuan.Berdasarkan tabel 6, tampak bahwa hubungan persepsi siswa mengenai variasi mengajar guru dengan hasil belajar matematika siswa ditunjukkan oleh koefisien korelasi (R) sebesar 0,170. Besarnya pengaruh persepsi siswa mengenai variasi mengajar guru terhadap hasil belajar matematika dapat dilihat pada koefisien determinasi ( $\mathrm{R}$ Square) yaitu 0,029 artinya persentase sumbangan pengaruh persepsi siswa mengenai variasi mengajar hanya sebesar $2,9 \%$. Sedangkan sisanya sebesar $97,1 \%$ dipengaruhi oleh faktor lain yang tidak diteliti dalam penelitian ini.

Tabel 6

Hasil Koefisien Korelasi persepsi siswa mengenai variasi mengajar

Terhadap Hasil Belajar Matematika Siswa

Model Summary

\begin{tabular}{|l|r|r|r|r|}
\hline Model & $\mathrm{R}$ & $\mathrm{R}$ Square & $\begin{array}{c}\text { Adjusted } \\
\mathrm{R} \text { Square }\end{array}$ & $\begin{array}{c}\text { Std. Error of } \\
\text { the Estimate }\end{array}$ \\
\hline 1 &, $170^{\mathrm{a}}$ &, 029 &, 023 & 14,09621 \\
\hline
\end{tabular}

a. Predictors: (Constant), Persepsi_Siswa

Uji regresi berganda antara variabel gaya belajar $\left(\mathrm{X}_{1}\right)$ dan variabel persepsi siswa mengenai variasi mengajar $\left(\mathrm{X}_{2}\right)$ secara bersama- sama terhadap hasil belajar matematika (Y) dapat dilihat pada tabel 7 berikut.

Tabel 7

Hasil Uji F Variabel Gaya Belajar dan Persepsi Siswa mengenai Variasi Mengajar Guru secara Bersama-sama terhadap Hasil Belajar Matematika Siswa SMPN 5 Kendari

ANOVA

\begin{tabular}{|rl|r|r|r|r|r|}
\hline \multicolumn{1}{|c|}{} & \multicolumn{1}{c|}{$\begin{array}{c}\text { Sum of } \\
\text { Sodel }\end{array}$} & \multicolumn{1}{c|}{ df } & Mean Square & \multicolumn{1}{c|}{$\mathrm{F}$} & Sig. \\
\hline 1 & Regression & 6855,301 & 2 & 3427,651 & 20,742 &, $000^{\mathrm{a}}$ \\
& Residual & 27927,925 & 169 & 165,254 & & \\
& Total & 34783,227 & 171 & & & \\
\hline
\end{tabular}

a. Predictors: (Constant), Persepsi_Siswa, Gaya_Belajar

b. Dependent Variable: HBM

Berdasarkan tabel 7, diperoleh bahwa sig = 0,000 lebih kecil dari $\alpha=0,05$ yang dipilih atau dengan memperhatikan $\mathrm{F}_{\text {hitung }}=20,742$, selanjutnya dibandingkan dengan $\mathrm{F}_{\text {tabel }}$ dengan $\mathrm{dk}$ pembilang $=2$ dan $\mathrm{dk}$ penyebut $=\mathrm{n}-\mathrm{k}-1=$ $172-2-1=169$. Dengan taraf kesalahan 5\%, maka harga $\mathrm{F}_{\text {tabel }}$ yang diperoleh $=3,05$. Ternyata $F_{\text {hitung }}=20,742>F_{\text {tabel }}=3,05$. Hal ini menunjukkan diterimanya hipotesis $\mathrm{H}_{1}$ dan tolak $\mathrm{H}_{0}$. Artinya ada pengaruh yang signifikan gaya belajar dan persepsi siswa mengenai variasi mengajar guru secara bersama-sama terhadap hasil belajar matematika siswa kelas VIII SMP Negeri 5 Kendari. Persamaan regresi yang diperoleh yaitu $\hat{Y}=-31,000+0,658 X_{1}+0,292 X_{2}$ dari hasil persamaan uji regresi berganda tersebut, maka dapat diartikan: 1) Koefisien regresi gaya belajar $\left(\mathrm{X}_{1}\right)$ bernilai positif sebesar 0,658 artinya apabila gaya belajar siswa meningkat sebesar 1 satuan maka hasil belajar matematika siswa akan meningkat pula sebesar 0,658 satuan dengan asumsi variabel lain tetap. 2) Koefisien regresi persepsi siswa mengenai variasi mengajar guru $\left(\mathrm{X}_{2}\right)$ bernilai positif sebesar 0,292 artinya apabila persepsi siswa mengenai variasi mengajar guru meningkat sebesar 1 satuan maka hasil belajar matematika siswa akan meningkat pula sebesar 0,292 satuan dengan asumsi variabel lain tetap.

Berdasarkan hasil analisis regresi ganda, tampak bahwa hubungan gaya belajar dan persepsi siswa mengenai variasi mengajar guru dengan hasil belajar matematika siswa 
ditunjukkan oleh koefisien korelasi (R) sebesar 0,444 . Besarnya pengaruh gaya belajar dan persepsi siswa mengenai variasi mengajar guru secara bersama-sama terhadap hasil belajar matematika dapat dilihat pada koefisien determinasi ( $\mathrm{R}$ Square) yaitu 0,197yang menunjukkan bahwa hasil belajar matematika siswa kelas VIII SMP Negeri 5 Kendari dipengaruhi oleh gaya belajar dan persepsi siswa mengenai variasi mengajar guru secara bersamasama sebesar $19,7 \%$ sedangkan sisanya sebesar $81,3 \%$ dipengaruhi oleh faktor lain yang tidak diteliti dalam penelitian ini.

Tabel 8

Hasil Koefisien Korelasi Gaya Belajar dan Persepsi Siswa mengenai

Variasi Mengajar terhadap Hasil Belajar Matematika Siswa

Model Summary

\begin{tabular}{|l|r|r|r|r|}
\hline Model & $R$ & $R$ Square & $\begin{array}{c}\text { Adjusted } \\
\text { R Square }\end{array}$ & $\begin{array}{c}\text { Std. Error of } \\
\text { the Estimate }\end{array}$ \\
\hline 1 &, $170^{a}$ &, 029 &, 023 & 14,09621 \\
\hline
\end{tabular}

a. Predictors: (Constant), Persepsi_Siswa

\section{Pembahasan}

Berdasarkan hasil pengujian hipotesis ANOVA pada siswa yang memiliki gaya belajar yang berbeda menunjukkan adanya perbedaan hasil belajar matematika antara kelompok siswa yang memiliki gaya belajar visual, dengan kelompok siswa yang memiliki gaya belajar auditorial dan kelompok siswa yang memiliki gaya belajar kinestetik. Perbedaan ini ditandai dengan perolehan rata-rata hasil belajar matematika dimana siswa yang memiliki gaya belajar visual $(\mu=70,40)$ lebih tinggi daripada nilai rata-rata hasil belajar matematika siswa yang memiliki gaya belajar kinestetik $(\mu=$ $69,13)$ dan auditorial $(\mu=63,80)$.Perbedaan ini juga diperkuat dengan ANOVA yang memperlihatkan harga $F$-hitung sebesar 3,240 dengan $\mathrm{F}_{\text {tab }}=\left(\alpha=0,05 ; \mathrm{df}_{1} / \mathrm{df}_{2}\right)=2 / 169=3,05$ memiliki nilai sig. sebesar $0,042(\operatorname{sig}<0,05)$ pada taraf signifikan $\alpha=5 \%$. Hal ini memperkuat hipotesis bahwa gaya belajar siswa yang berbeda akan memberikan hasil belajar matematika yang berbeda pula.

Setiap siswa memiliki gaya belajar yang berbeda, berkenaan dengan itu maka sudah seharusnya seorang guru mengetahui gaya belajar para siswanya. Sehingga, dalam menyampaikan materi pelajaran dalam hal ini pelajaran matematika diperlukan kreatifitas seorang guru agar dapat menciptakan sebuah pengajaran yang menyenangkan dan cocok bagi seluruh siswanya. Hasil penelitian skripsi ini sesuai dengan apa yang di kemukakan oleh Danaryanti dan Noviani (2015) bahwa rata-rata nilai akhir kemampuan komunikasi matematis yang dimiliki kelompok siswa bergaya belajar visual $(\mu=25,03)$ lebih besar dibandingkan dengan kelompok siswa bergaya belajar auditorial $(\mu=23,88)$ dan maupun kelompok siswa bergaya belajar kinestetik $(\mu=13,53)$.

Hal ini tidak dapat diartikan bahwa gaya belajar visual lebih baik daripada gaya belajar auditorial dan kinestetik begitupun sebaliknya. Pada dasarnya ketiga gaya belajar ini sama, yang membedakan adalah tergantung dari cara seseorang belajar dalam menggunakan gaya belajar mereka secara optimal. Sesuai dengan yang dijelaskan oleh Gunawan (2013) bahwa siswa yang belajar dengan menggunakan gaya belajarnya yang dominan akan mendapatkan hasil belajar yang lebih baik karena siswa dapat belajar dengan efektif.

Berdasarkan hasil analisis regresi sederhanadata gaya belajar terhadap hasil belajar matematika diperoleh nilai $t_{\text {hitung }}=6,249>t_{\text {tabel }}=$ 1,974 dan nilai sig $=0,000$ lebih kecil dari $\alpha$ yang ditetapkan yakni 0,05. Artinya, gaya belajar mempunyai pengaruh yang signifikan terhadap hasil belajar matematika siswa kelas VIII SMP Negeri 5 Kendari. Dari hasil penelitian ini besarnya pengaruh atau kontribusi gaya belajar terhadap hasil belajar matematika siswa kelas VIII SMP Negeri 5 Kendari ditunjukkan dengan hasil perhitungan koefisien determinasi ( $R$ Square) yaitu 0,187 artinya persentase sumbangan pengaruh gaya belajar hanya sebesar $18,7 \%$. Sedangkan sisanya sebesar $81,3 \%$ dipengaruhi oleh faktor lain yang tidak dibahas dalam penelitian ini. Hal ini sesuai dengan penelitian yang dilakukan Syukur (2016) yang menyimpulkan bahwa terdapat pengaruh yang signifikan gaya belajar terhadaphasil 
belajar matematika siswa kelas XI SMAN 4 Kendari.

Selanjutnya, dari hasil analisis regresi sederhana antara gaya belajar siswa dan hasil belajar matematika siswa kelas VIII SMP Negeri 5 Kendari diperoleh persamaan regresi yaitu $\hat{Y}=-17,992+0,684 X_{1}$. Ini dapat diartikan bahwa ada kecenderungan positif terhadap gaya belajar dan diperoleh suatu kesimpulan bahwa persamaan regresi ini dapat digunakan untuk memprediksi nilai hasil belajar matematika siswa jika skor gaya belajarnya diketahui. Mengacu pada fungsi taksiran regresi itu, dapat dijelaskan bahwa koefisien arah regresi $X_{1}$ sebesar 0,684 berarti setiap kenaikan 1 satuan variabel gaya belajar $\left(\mathrm{X}_{1}\right)$ maka akan diikuti dengan meningkatnya nilai hasil belajar matematika siswa sebesar 0,684 satuan.

Gaya belajar memiliki tempat yang penting dalam kehidupan individu. Peserta didik atau siswa adalah individual yang memiliki keunikan berbeda satu sama lain dan tidak satupun yang memiliki ciri-ciri sama persis meskipun mereka kembar. Setiap individu pasti memiliki karakteristik yang berbeda dengan yang lainnya. Sama halnya dengan gaya belajar yang dimiliki setiap individu atau siswa antara satu dan lainnya. Gaya belajar merupakan implementasi siswa dalam mengkombinasikan penyerapan, pengaturan serta pengolahan informasi yang telah didapat. Ketika individu tahu gaya belajarnya maka ia akan mengintegrasikannya dalam proses pembelajaran sehingga dia akan belajar lebih banyak, mudah, cepat dan akan berhasil (Gilakjani, 2012: 109). Hal ini diperkuat oleh teori De Porter (2015) yang menyatakan bahwa "jika Anda akrab dengan gaya belajar Anda sendiri, Anda dapat mengambil langkah-langkah penting untuk membantu diri Anda belajar lebih cepat dan lebih mudah." Anda disini maksudnya adalah semua orang tidak terkecuali peserta didik atau siswa.

Berdasarkan hasil analisis regresi sederhana data persepsi siswa mengenai variasi mengajar guru terhadap hasil belajar matematikadapat disimpulkan bahwa persepsi siswa mengenai variasi mengajar guru mempunyai pengaruh yang signifikan terhadap hasil belajar matematika siswa kelas VIII SMP Negeri 5 Kendari.. Dari hasil penelitian ini besarnya pengaruh atau kontribusi persepsi siswa mengenai variasi mengajar guru terhadap hasil belajar matematika siswa kelas VIII SMP Negeri 5 Kendari pada koefisien determinasi $(R$ Square) yaitu 0,029 artinya persentase sumbangan pengaruh gaya belajar hanya sebesar $2,9 \%$. Sedangkan sisanya sebesar $97,1 \%$ dipengaruhi oleh faktor lain yang tidak dibahas dalam penelitian ini.

Hal ini sesuai dengan penelitian yang dilakukan Lulan (2015) yang menyimpulkan bahwa ada pengaruh yang positif dan signifikan persepsi siswa tentang variasi mengajar guru terhadap hasil belajar IPS terpadu Siswa Kelas VIII SMP Negeri 1 Kupang Semester Ganjil Tahun Pelajaran 2013/2014. Hasil analisis lebih lanjut antara persepsi siswa mengenai variasi mengajar guru dan hasil belajar matematika siswa kelas VIII SMP Negeri 5 Kendari diperoleh Persamaan regresi yaitu $\hat{Y}=41,274+0,482 X_{2}$. Ini dapat diartikan bahwa ada kecenderungan positif terhadap persepsi siswa mengenai variasi mengajar gurudan diperoleh suatu kesimpulan bahwa persamaan regresi ini dapat digunakan untuk memprediksi nilai hasil belajar matematika siswa. Mengacu pada fungsi taksiran regresi itu, dapat dijelaskan bahwa koefisien arah regresi $\mathrm{X}_{2}$ sebesar 0,482 berarti setiap kenaikan 1 satuan variabel persepsi siswa mengenai variasi mengajar guru $\left(\mathrm{X}_{2}\right)$ maka akan diikuti dengan meningkatnya nilai hasil belajar matematika siswa sebesar 0,482 satuan.

Hasil analisis tersebut, didukung oleh pendapat Slameto (2015: 102) persepsi adalah proses yang menyangkut masuknya pesan atau informasi ke dalam otak manusia. Melalui persepsi manusia terus-menerus mengadakan hubungan dengan lingkungannya. Hubungan ini dilakukan lewat inderanya, yaitu indera penglihat, pendengar, peraba, perasa dan pencium. Jika persepsi siswa tentang variasi mengajar guru positif maka hasil belajar akan meningkat dan sebaliknya, jika persepsi siswa tentang variasi mengajar guru negatif maka hasil belajar siswa akan rendah. Variasi mengajar guru merupakan faktor eksternal yang dapat mempengaruhi hasil belajar siswa. Dalam bukunya, Winataputra (2000: 7.45 - 7.46) menjelaskan bahwa variasi di dalam kegiatan pembelajaran bertujuan antara lain untuk: 1) menghilangkan kebosanan siswa dalam belajar; 2) meningkatkan motivasi siswa dalam mempelajari sesuatu; 3) mengembangkan keinginan siswa untuk mengetahui dan 
menyelidiki hal-hal baru; 4) melayani gaya belajar siswa yang beraneka ragam; serta 5) meningkatkan kadar keaktifan/keterlibatan siswa dalam kegiatan pembelajaran. Hal ini diperkuat dengan yang dijelaskan Othman dan Amiruddin (2010:1) bahwa guru harus kreatif dalam teknik pendidikan di kelas yakni guru harus mengerti akan kebutuhan belajar siswa dengan memberikan rangsangan agar siswa tertarik dalam kegiatan pembelajaran dan langsung memusatkan perhatian saat guru memberikan penjelasan.

Berdasarkan hasil analisis regresi ganda untuk gaya belajar dan persepsi siswa mengenai variasi mengajar guru secara bersama-sama terhadap hasil belajar matematika diperoleh bahwa gaya belajar dan persepsi siswa mengenai variasi mengajar guru mempunyai pengaruh yang signifikan terhadap hasil belajar matematika siswa kelas VIII SMP Negeri 5 Kendari. Dari hasil penelitian ini, besarnya pengaruh atau kontribusi gaya belajar dan persepsi siswa mengenai variasi mengajar guru terhadap hasil belajar matematika siswa kelas VIII SMP Negeri 5 Kendari pada koefisien determinasi ( $R$ Square) yaitu 0,197 artinya persentase sumbangan pengaruh gaya belajar hanya sebesar 19,7\%. Sedangkan sisanya sebesar $80,3 \%$ dipengaruhi oleh faktor lain yang tidak dibahas dalam penelitian ini. Besarnya hubungan gaya belajar dan persepsi siswa mengenai variasi mengajar guru secara bersamasama terhadap hasil belajar matematika siswa, ditunjukkan oleh koefisien korelasi (R) sebesar 0,444 . Persamaan regresi berganda yang diperoleh yaitu $\hat{Y}=-31,000+0,658 X_{1}+0,292 X_{2}$. Ini dapat diartikan bahwa ada kecenderungan positif gaya belajar dan persepsi siswa mengenai variasi mengajar gurudan diperoleh suatu kesimpulan bahwa persamaan regresi ini dapat digunakan untuk memprediksi nilai hasil belajar matematika siswa jika skor gaya belajar dan persepsi siswa mengenai variasi mengajar gurunya diketahui. Mengacu pada fungsi taksiran regresi itu, dapat dilihat bahwa: 1) koefisien arah regresi $\mathrm{X}_{1}$ sebesar 0,658 ini berarti setiap kenaikan 1 satuan variabel skor gaya belajar maka akan diikuti dengan meningkatnya nilai hasil belajar matematika siswa sebesar 0,658 satuan. 2) koefisien arah regresi $\mathrm{X}_{2}$ sebesar 0,292 ini berarti setiap kenaikan 1 satuan variabel skor persepsi siswa mengenai variasi mengajar guru maka akan diikuti dengan meningkatnya nilai hasil belajar matematika siswa sebesar 0,292 satuan.

Gaya belajar dan persepsi siswa mengenai variasi mengajar guru secara bersamasama mempunyai pengaruh yang signifikan terhadap hasil belajar matematika. Hal ini sesuai dengan yang dikemukakan oleh Wijaya (Sahidin dan Jamil, 2013: 219), yang mengatakan bahwa guru harus mampu menciptakan suasana di dalam proses pembelajaran agar terjadi interaksi belajar mengajar yang dapat memotivasi siswa untuk belajar dengan baik dan sungguhsungguh. Maka dari itu, mengajar yang baik akan terwujud jika ada variasi pada saat menyajikan materi dan variasi tersebut di sesuaikan dengan karakteristika atau gaya belajar siswa yang berbeda-beda.

Berdasarkan hasil analisis regresi sederhana untuk setiap variabel bebas terhadap variabel terikat di atas, dapat dilihat bahwa nilai koefisien determinasi variabel gaya belajar lebih besar di bandingkan koefisien determinasi persepsi siswa mengenai variasi mengajar guru. Hal ini menunjukkan bahwa gaya belajar memberikan pengaruh yang lebih besar di bandingkan persepsi siswa mengenai variasi mengajar guru terhadap pencapaian hasil belajar matematika.

\section{Simpulan dan Saran}

\section{Simpulan}

Berdasarkan hasil analisis dan pembahasan yang diperoleh maka dapat disimpulkan bahwa:

1. Terdapat perbedaan antara hasil belajar matematika siswa yang memiliki gaya belajar visual, auditorial dan kinestetik. Siswa yang memiliki gaya belajar visual memiliki rata-rata hasil belajar matematika yang lebih tinggi yaitu 70,403 dari nilai rata-rata hasil belajar matematik siswa bergaya belajar kinestetik yaitu 69,130 dan siswa bergaya belajar auditorialsebesar 63,804. Ini ditunjukan dengan perolehan $\mathrm{F}_{\text {hit }}=3,240 ;$ dengan $\mathrm{F}_{\text {tab }}=\left(\alpha=0,05 ; \mathrm{df}_{1} / \mathrm{df}_{2}\right)$ $=2 / 169=3,05$ memiliki nilai sig. sebesar 0,042 kurang dari 0,05 .

2. Terdapat pengaruh yang signifikan Gaya belajar $\left(\mathrm{X}_{1}\right)$ terhadap hasil belajar matematika (Y) siswa SMP Negeri 5 Kendari. Pengaruh gaya belajar dilihat dari 
besarnya koefisien determinasi yakni sebesar $18,7 \%$ sedangkan sisanya sebesar $81,3 \%$ dipengaruhi oleh variabel lain. Selain itu, ditunjukkan pula pada persamaan regresi $\hat{Y}=-17,992+0,684 X_{1}$. Ini dapat diartikan bahwa ada kecenderungan positif terhadap gaya belajar. Implikasinya semakin optimal siswa menggunakan gaya belajar yang dominan maka semakin tinggi pula hasil belajar matematika yang diperoleh.

3. Terdapat pengaruh yang signifikan persepsi siswa mengenai variasi mengajar guru $\left(\mathrm{X}_{2}\right)$ terhadap hasil belajar matematika (Y) siswa SMP Negeri 5 Kendari. Pengaruh persepsi siswa mengenai variasi mengajar guru dilihat dari besarnya koefisien determinasi yakni sebesar 2,9\% sedangkan sisanya sebesar $97,1 \%$ dipengaruhi oleh variabel lain. Selain itu, ditunjukkan pula pada persamaan regresi $\hat{Y}=41,274+0,482 X_{2}$. Ini dapat diartikan bahwa ada kecenderungan positif terhadap persepsi siswa mengenai variasi mengajar guru. Implikasinya semakin baik persepsi siswa mengenai variasi mengajar guru maka semakin tinggi pula hasil belajar matematika yang diperoleh.

4. Terdapat pengaruh yang signifikan gaya belajar $\left(\mathrm{X}_{1}\right)$ dan persepsi siswa mengenai variasi mengajar guru $\left(\mathrm{X}_{2}\right)$ secara bersamasama terhadap hasil belajar matematika $(\mathrm{Y})$ siswa SMP Negeri 5 Kendari. Pengaruh tersebut dapat dilihat pada koefisien determinasi yakni sebesar 19,7\% sedangkan sisanya sebesar $80,3 \%$ dipengaruhi oleh variabel lain. Selain itu, ditunjukkan pula pada persamaan regresi $\hat{Y}=-31,000+0,658 X_{1}+0,292 X_{2}$.

Implikasinya semakin baik gaya belajar dan persepsi siswa mengenai variasi mengajar guru maka semakin tinggi pula hasil belajar matematika yang diperoleh.

\section{Saran}

Berdasarkan pembahasan dan kesimpulan hasil penelitian, maka penulis memberikan saran-saran sebagai berikut:

1. Untuk meningkatkan gaya belajar siswa kelas VIII SMP Negeri5 Kendari secara optimal, aspek penting yang harus diperhatikan adalah karakter dari masingmasing siswa. Bagi guru, sebaiknya dalam proses pembelajaran lebih memperhatikan gaya belajar siswa. Karena dengan mengetahui gaya belajar siswa yang berbeda-beda, hal ini dapat membantu setiap guru untuk dapat mendekati semua murid dengan cara menyampaikan dan memberikan pembelajaran dengan gaya mengajar yang berbeda-beda sehingga siswa pun dapat memahami pembelajaran yang berlangsung.

2. Untuk meningkatkan persepsi siswa terhadap variasi mengajar guru kelas VIII SMP Negeri 5 Kendari, aspek penting yang harus diperhatikan adalah variasi gaya mengajar, penggunaan media dan bahan pembelajaran, dan pola interaksi. Bagi guru, sebaiknya dalam proses pembelajaran mengadakan variasi mengajar sehingga akan memberikan siswa kesan bahwa pembelajaran tidak akan membosankan dan tidak terkesan monoton, dengan begitu siswa akan lebih aktif karena terlibat langsung menggunakan media pembelajaran serta berinteraksi dengan teman dan guru melalui diskusi.

\section{Daftar Pustaka}

Aqib, Zainal. (2013). Model-model, media, dan strategi pembelajaran kontekstual (inovatif). Bandung: Yrama Widya.

Danaryanti, Agni dan Herlina Noviani. (2015). Pengaruh Gaya Belajar Matematika Siswi Kelas VII terhadap Kemampuan Komunikasi Matematis Di SMP. Jurnal Pendidikan Matematika. Volume 3, Nomor 2 (hlm 204 - 212).

Deporter, Bobbi dan Mike Hernacki. (2015). Quantum Learning: Membiasakan Belajar Nyaman dan Menyenangkan. Bandung: Kaifa.

Fatma, Firdaus Yulia. (2010). Pengaruh Gaya Belajar Dan Motivasi Belajar terhadap Prestasi Belajar Siswa Kelas SMA. Skripsi Fakultas Ekonomi Unesa Surabaya.

Gilakjani, Abbas Pourhossein. (2012). Visual, Auditory, Kinaesthetic and Their 
Impacts on English Language Teaching. Journal of Studies in Education. ISSN: 2162 - 6952. 2012, Vol. 2 No.1 (Hal $104-113)$.

Gunawan, Muhammad Ali. (2013). Statistik untuk Penelitian Pendidikan. Yogyakarta: Parama Publishing.

Jihad, Asep dan Abdul Haris. (2013). Evaluasi Pembelajaran. Yogyakarta: Multi Pressindo.

Lulan, Yuninda Anaci. (2015). Pengaruh Persepsi Siswa tentang Variasi Mengajar Guru dan Cara Belajar Siswa terhadap Hasil Belajar IPS Terpadu Siswa Kelas VIII SMP Negeri 1 Kupang. Tesis Program Pascasarjana Universitas Sebelas Maret Surakarta.

Mulyadi, Seto, dkk. (2016). Psikologi Pendidikan:dengan Pendekatan TeoriTeori Baru Dalam Psikologi. Jakarta: Rajawali Pers.

Othman, Norasmah dan Mohd Hasril Amiruddin. (2010). Different Perspectives of Learning Styles from VARK Model.Procedia Social and Behavioral Sciences 7(C) (2010) 652660.

Sahidin, Latief dan Dini Jamil. (2013). Pengaruh Motivasi Berprestasi dan Persepsi Siswa Tentang Cara Guru Mengajar Terhadap Hasil Belajar Matematika. Jurnal Pendidikan Matematika Volume 4 Nomor 2.
Sartika, Wa Ode. (2013). Pengaruh Persepsi Siswa Tentang Cara Mengajar Guru dan Kebiasaan Belajar Siswa Terhadap Hasil Belajar Matematika Siswa Kelas X SMA Negeri 1 Sawerigedi Tahun Ajaran 2012/2013. Skripsi Fakultas Keguruan dan Ilmu Pendidikan Universitas Halu Oleo: Kendari.

Septiana, Anisa. (2016). Hubungan Gaya Belajar Dan Persepsi Siswa tentang Metode Mengajar Guru Terhadap Prestasi Belajar Matematika pada Siswa-Siswi Kelas XI SMA Negeri 1 Sangatta Utara Kutai Timur.eJournal Psikologi 4(2): 165 - 176. ISSN: 2477 2674.

Slameto. (2015). Belajar dan Faktor-Faktor yang Mempengaruhinya. Jakarta: Rineka Cipta.

Syukur, Muhammad. (2016). Hubungan Antara Gaya Belajar dengan Hasil Belajar Matematika Siswa Kelas XI SMAN 4 Kendari. Skripsi FKIP UHO: Kendari.

Thobroni M. (2016). Belajar dan Pembelajaran: Teori dan Praktik. Yogyakarta: Ar-Ruzz Media.

Tim Penyusun KBBI. (2007). Kamus Besar Bahasa Indonesia (edisi ketiga). Jakarta: Balai Pustaka.

Winataputra, H. Udin S. (2000). Strategi Belajar Mengajar. Jakarta: Universitas Terbuka. 